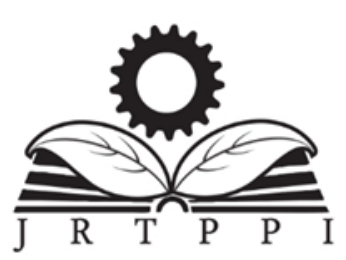

Vol. 10 No. 1 (2019) 22-28

Jurnal Riset

Teknologi Pencegahan Pencemaran Industri

Kementerian

Perindustrian

REPUBLIK INDONESIA

Journal homepage : ejournal.kemenperin.go.id/jrtppi

\title{
A Preliminary Result of Air Quality Identification and Analysis of PM10 and PM2.5 in Steel Industrial Area, Cilegon, Banten
}

\author{
Ira Setiawati ${ }^{1}$, Rahyani Ermawati ${ }^{1}$, Kitai Kang ${ }^{2}$, Insoo Chang ${ }^{2}$, Kihwan Hong ${ }^{2}$, Ervina ${ }^{1}$, Auliyah Ariani ${ }^{1}$, Ilham Fauzi ${ }^{1}$, Indra \\ Lukman Syah ${ }^{1}$, Fita Sefriana ${ }^{1}$, and Yesy Komala Sari ${ }^{1}$ \\ ${ }^{1}$ Center for Chemical and Packaging, Jl. Balai Kimia I Pekayon, Pasar Rebo, Jakarta, Republic of Indonesia \\ ${ }^{2}$ Aerosol Research and Technology Plus, 195-62, Daepyeong-ro, Daewol-myeon, Icheon-si, Gyeonggi-do, 17343, Republic of Korea
}

\section{A R T I C L E IN F O \\ Article History:}

Received 26 February 2019

Received in revised form 15 April 2019

Accepted 25 April 2019

Available online 27 May 2019

\section{Keywords :}

Air quality

Particulate matter

Steel industry

Low volume sampler (LVS)

\begin{abstract}
A B S T R A C T
The increasingly rapid industrial development has produced pollutants in the form of gases and particles polluting the atmosphere. One of them is the steel industry where the majority of the air pollutants produced is particulate matter. Monitoring the air quality of particulate matter needs to be done routinely to identify and control the effects of air pollution somewhere. The purpose of this study is to identify and analyze particulate matter $\left(\mathrm{PM}_{10}\right.$ and $\left.\mathrm{PM}_{2.5}\right)$ in the steel industry area in Cilegon, Indonesia. Ambient particulate matter is sampling by low-volume Sequential Particulate Matter (PM) Sampler with flow rate 5-20 L/minute for 24 hours per day in 4 months from September 2018 to January 2019 at four sampling locations (main gate area, hot strip mill area, billet post area, and hot blast plant area). The results of identification and analysis showed concentrations that varied greatly depending on sampling location conditions, with an average concentration range of $89.38-141.13 \mu \mathrm{g} / \mathrm{m}^{3}$ for $\mathrm{PM}_{10}$ and $21.74-50.69 \mu \mathrm{g} / \mathrm{m}^{3}$ for $\mathrm{PM}_{2.5}$. The maximum concentration of $\mathrm{PM}_{10}$ measured was $338.06 \mu \mathrm{g} / \mathrm{m}^{3}$ at Point 4 (the hot blast plant area) on Day 65 and the minimum concentration was $16.67 \mu \mathrm{g} / \mathrm{m}^{3}$ at Point 3 (the billet post area) on Day 11. While, the maximum concentration of $\mathrm{PM}_{2.5}$ was $141.96 \mu \mathrm{g} / \mathrm{m}^{3}$ at Point 3 on Day 82 and the minimum concentration was $4.19 \mu \mathrm{g} / \mathrm{m}^{3}$ at Point 4 on Day 99.
\end{abstract}

\section{INTRODUCTION}

One of the priority industries being developed by the Indonesian Ministry of Industry is the steel industry. This sector functions as the mother of an industry because its products are the main of raw material for other industrial sector activities. Steel also has a vital role in daily life because of its use in various fields (for example construction, vehicles, manufacturing, energy transfer, etc.). As a result of urbanization and industrialization and to fulfill this demand, there has been an increase in the number of steelmaking factories throughout the world. The rapid expansion of the steel-producing industry has produced emissions that are also large in the form of gases and particles polluting the atmosphere. The types of pollutants include $\mathrm{SO}_{2}, \mathrm{CO}, \mathrm{NO}_{x}$, and particles with an aerodynamic diameter of less than $10 \mu \mathrm{m}$ (Wahab et al., 2018; Jia et al., 2018; Kumar et al., 2018). The amount of pollutants emitted outside the industrial area can be influenced by the type and capacity of the fuel and the height of the stack used by industry (Ruhiat et al., 2017).

However, the majority of air pollutants produced from industrial process activities such as iron and steel milling and metal smelting are particulate matter. The sampling results from iron and steel industry in China showed that the highest particle mass concentration (the size

${ }^{*}$ Correspondence author. Tel. : $x x x x x x x x x$

E-mail : ira.setiawati@gmail.com

doi : $\operatorname{xxxxxxxxxxx}$

2503-5010/2087-0965@ 2018 Jurnal Riset Teknologi Pencegahan Pencemaran Industri-BBTPPI (JRTPPI-BBTPPI).

This is an open acces article under the CC BY-NC-SA license (https://creativecommons.org/licenses/by-nc-sa/4.0/).

Accreditation number : (LIPI) 756/Akred/P2MI-LIPI/08/2016 


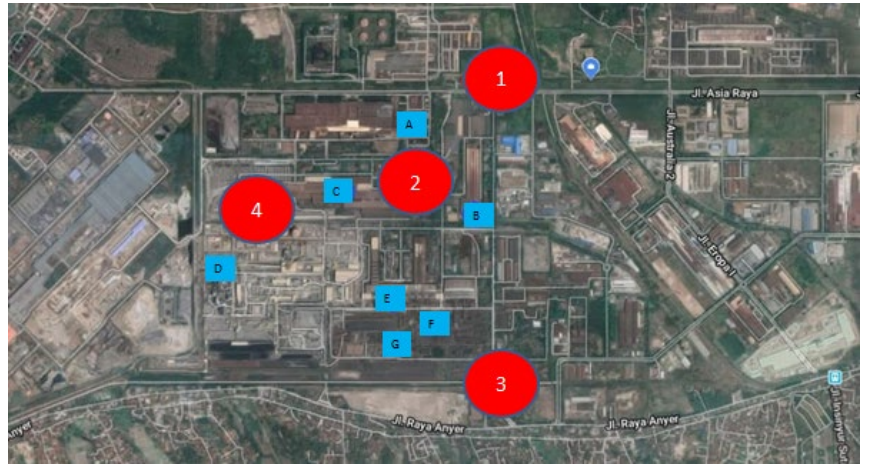

Figure 1. Sampling locations in the steel industrial area, Cilegon, Indonesia

distributions of particle mass ranging between 0.43 and 10 $\mu \mathrm{m})$ was $40.8 \mathrm{mg} / \mathrm{m}^{3}$ (Jia et al., 2018). Other study was mentioned that the mass concentration of the sampled fine and coarse PM fraction from a scrap iron and steel smelting industry in Nigeria ranged between $14.4-986.5 \mu \mathrm{g} / \mathrm{m}^{3}$ and $11.2-3250 \mu \mathrm{g} / \mathrm{m}^{3}$, respectively (Owoade et al., 2015).

PM stands for particulate matter (also called particle pollution): the term for a mixture of solid particles and liquid droplets found in the air. Some particles, such as dust, dirt, soot, or smoke, are large or dark enough to be seen with the naked eye. Others are so small they can only be detected using an electron microscope. Particle pollution includes $\mathrm{PM}_{10}$ and $\mathrm{PM}_{2.5}$. $\mathrm{PM}_{10}$ are inhalable particles, with diameters that are generally 10 micrometers and smaller; and $\mathrm{PM}_{2.5}$ are fine inhalable particles, with diameters that are generally 2.5 micrometers and smaller. These particles come in many sizes and shapes and can be made up of hundreds of different chemicals. Some are emitted directly from a source, such as construction sites, unpaved roads, fields, smokestacks or fires. Most particles form in the atmosphere as a result of complex reactions of chemicals such as sulfur dioxide and nitrogen oxides, which are pollutants emitted from power plants, industries, and automobiles (U.S. EPA, 2018).

Along with the technology development and the presence of air quality standards, dust sampling has begun to be carried out with effective, efficient and safe methods. This method is very necessary for air quality monitoring routinely and continuously for several days, so that it can assist in assessing risk and applying control measures

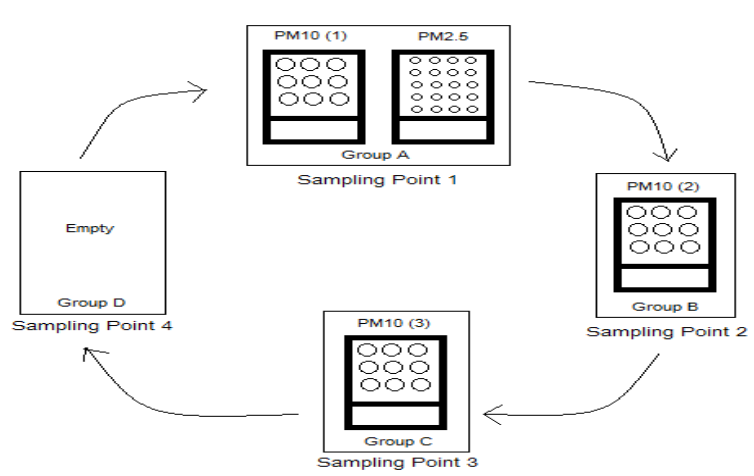

Figure 2. Detail of Particulate Matter sampler position on the first rotation

quickly. While advanced countries including US, Japan, and European nations have evolved advanced monitoring systems, most developing countries of Asia and Africa are still languishing with very basic monitoring or no monitoring at all (Roychowdhury et al., 2016). Based on Air Quality Index Calculation (2019), more than 88 countries have a monitoring system, include Indonesia. Some countries in Asia were no monitoring at all or ongoing, such as: Cambodia, Kyrgyzstan, Myanmar, and Sri Lanka. For monitoring, PM concentration can be measured by several methods, such as gravimetric, optical, microbalance, and electrical charge. These measuring methods have been reviewed the advantages and the disadvantages. Some countries can choose the method depending on their regulation or the ease of getting the equipment (Amaral et. al., 2015; Budde et. al., 2013).

In this study, air quality monitoring was carried out by identifying and analyzing the air quality of ambient particulate matters in the steel industry in Cilegon, Indonesia using a gravimetric method, where the standard method used in Indonesia (SNI 7119.15: 2016). The results obtained are expected to be used as data and information to the authorities regarding ambient particulate matters in the steel industry in Indonesia so that they can take corrective actions following the established procedures for results that exceed the ambient dust standard. In addition, the existence of this research is also expected to encourage industries in Indonesia in addition to the steel industry to implement green industry standards. 
Table 1. Particulate Matter Sampler Position

\begin{tabular}{|c|c|c|c|c|}
\hline \multirow{2}{*}{ Sampling Period } & \multicolumn{4}{|c|}{ PM Sampler Position } \\
\hline & Point 1 & Point 2 & Point 3 & Point 4 \\
\hline $\begin{array}{l}\text { First Rotation } \\
\left(2018, \text { Sept } 18^{\text {th }}-\text { Oct } 15^{\text {th }}\right)\end{array}$ & $\begin{array}{l}\mathrm{PM}_{10} \text { Sampler, } \\
\mathrm{PM}_{2.5} \text { Sampler }\end{array}$ & $\mathrm{PM}_{10}$ Sampler & $\mathrm{PM}_{10}$ Sampler & Empty \\
\hline $\begin{array}{l}\text { Second Rotation } \\
\left(2018 \text {, Oct } 16^{\text {th }}-\text { Nov } 6^{\text {th }}\right)\end{array}$ & Empty & $\begin{array}{l}\mathrm{PM}_{10} \text { Sampler, } \\
\mathrm{PM}_{2.5} \text { Sampler }\end{array}$ & $\mathrm{PM}_{10}$ Sampler & $\mathrm{PM}_{10}$ Sampler \\
\hline $\begin{array}{l}\text { Third Rotation } \\
\left(2018 \text {, Nov } 7^{\text {th }}-\text { Dec } 10^{\text {th }}\right)\end{array}$ & $\mathrm{PM}_{10}$ Sampler & Empty & $\begin{array}{l}\mathrm{PM}_{10} \text { Sampler, } \\
\mathrm{PM}_{2.5} \text { Sampler }\end{array}$ & $\mathrm{PM}_{10}$ Sampler \\
\hline $\begin{array}{l}\text { Fourth Rotation } \\
\left(2018 \text {, December } 11^{\text {th }}-2019 \text {, }\right. \\
\left.\text { January } 16^{\text {th }}\right)\end{array}$ & $\mathrm{PM}_{10}$ Sampler & $\mathrm{PM}_{10}$ Sampler & Empty & $\begin{array}{l}\mathrm{PM}_{10} \text { Sampler, } \\
\mathrm{PM}_{2.5} \text { Sampler }\end{array}$ \\
\hline
\end{tabular}

\section{METHODS}

\subsection{Sampling Site}

The study was conducted in September 2018 until January 2019 in 4 different locations in one of the steel industries in Cilegon as a model. The sampling location is shown in Figure 1. Information from each point is as follows: Point 1 is the main gate area $\left(5^{\circ} 59^{\prime} 47.1^{\prime \prime} \mathrm{S}\right.$; $\left.106^{\circ} 00^{\prime} 21.3^{\prime \prime} \mathrm{E}\right)$, point 2 is the hot strip mill area (5059'50.2" S; $106^{\circ} 00^{\prime} 08.1^{\prime \prime} \mathrm{E}$ ), point 3 is the billet post area $\left(6^{\circ} 00^{\prime} 32.2^{\prime \prime} S ; 106^{\circ} 00^{\prime} 20.1^{\prime \prime} \mathrm{E}\right)$, and point 4 is the hot blast plant area $\left(6^{\circ} 00^{\prime} 11.9^{\prime \prime} \mathrm{S} ; 105^{\circ} 59^{\prime} 36.1^{\prime \prime} \mathrm{E}\right)$. Each point represents the location of the closest stack from different productions or plants. In order, Cold Rolling Mill Plant (A), Wire Rod Mill Plant (B), Hot Strip Mill Plant (C), Coke Oven Plant Blast Furnace (D), Slab Steel Plant (E and F), and Direct Reduction Plant (G).

This steel industry produced a number of main products such as Hot Rolled Coil, Cold Rolled Coil, and Wire Rod, with a production capacity of 3.15 million tons per year.

\subsection{Measurement}

The measurement method of particulate matters according to SNI 7119.15: 2016. Sampling is done for 24 hours per day. The sampling program for $\mathrm{PM}_{10}$ is set every seven days, while for $\mathrm{PM}_{2.5}$ is set every 3-4 days. The PM Samplers are rotated every one month at each sampling point to ensure the performance of them (Table 1 and Figure 2)

The main equipment used in this study are Sequential PM samplers [ART Plus APS-1897, Korea] with a low flow rate (5-20 L/minute), can be applied for 18-24 filter paper per program (operating 18-24 days), which is equipped with an application for setting up sampling and data storage (containing air volume data and environmental data such as temperature, pressure, humidity, and flow rate), and is equipped with 2 types of inlets namely $\mathrm{PM}_{10}$ Separation Device and $\mathrm{PM}_{2.5}$ Wins Impactor. The materials and tools used are filter paper PM $_{2.5}$ PTFE $46.2 \mathrm{~mm}$ [Tisch Scientific], filter paper $\mathrm{PM}_{10}$ Whatman QMA $47 \mathrm{~mm}$ [Advantec], analytic balance [Sartorius], and a flash disk installed on each device.

\section{RESULT AND DISCUSSION}

The identification and analysis results of $\mathrm{PM}_{10}$ and $\mathrm{PM}_{2.5}$ in the steel industrial area, Cilegon during the study can be seen in Figure 3 and Figure 4. In general, the composition of particulate matters obtained varies greatly every day and varies from place to place. The measured $\mathrm{PM}_{10}$ are $20.83-183.56 \mu \mathrm{g} / \mathrm{m}^{3}$ at Point 1, $25.00-276.04$ 


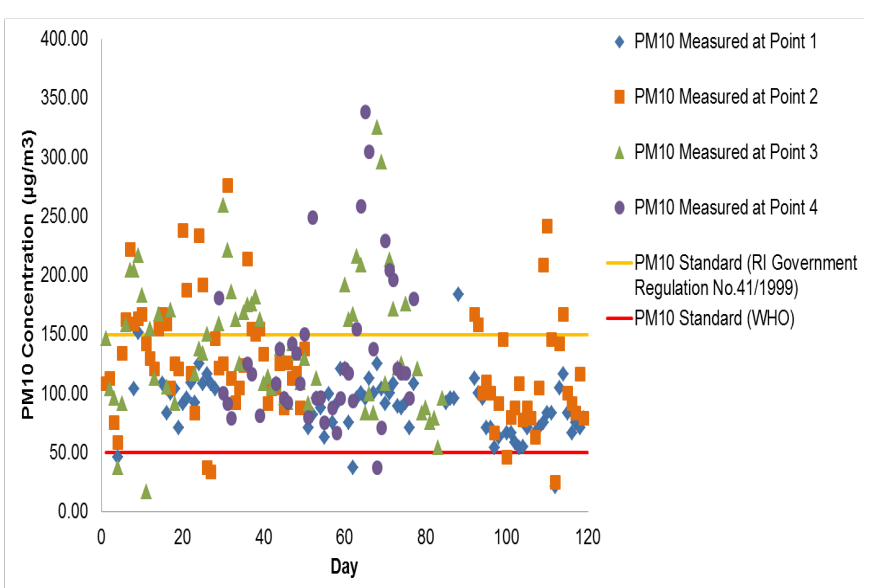

Figure 3. The $\mathrm{PM}_{10}$ concentration at each sampling point in the steel industry, Cilegon

$\mu \mathrm{g} / \mathrm{m}^{3}$ in Point 2, $16.67-325.00 \mu \mathrm{g} / \mathrm{m}^{3}$ in Point 3, and $37.53-338.06 \mu \mathrm{g} / \mathrm{m}^{3}$ at Point 4. Whereas the measured $\mathrm{PM}_{2.5}$ are $4.59-99.88 \mu \mathrm{g} / \mathrm{m}^{3}$ in Point $1,20.83-125.21$ $\mu \mathrm{g} / \mathrm{m}^{3}$ in Point 2, $29.25-141.96 \mu \mathrm{g} / \mathrm{m}^{3}$ in Point 3 and 4.19 $-41.67 \mu \mathrm{g} / \mathrm{m}^{3}$ in Point 4.

Based on ambient air quality standard, the concentration at each sampling location varies, some values met the standard and some exceed the standard. Republic of Indonesia Government Regulation Number 41 Year 1999 has the permissible daily limit of $150 \mu \mathrm{g} / \mathrm{m}^{3}$ for $\mathrm{PM}_{10}$ and $65 \mu \mathrm{g} / \mathrm{m}^{3}$ for $\mathrm{PM}_{2.5}$. While, the world standard issued by World Health Organization (WHO), has the permissible daily limit of $50 \mu \mathrm{g} / \mathrm{m}^{3}$ for $\mathrm{PM}_{10}$ and $25 \mu \mathrm{g} / \mathrm{m}^{3}$ for $\mathrm{PM}_{2.5}$ (WHO, 2018).

The location of the sampling location affects the amount of measured particulate matter. It can be seen that the highest concentration of $\mathrm{PM}_{10}$ obtained from each point, in the sequence were Point $4\left(338.06 \mu \mathrm{g} / \mathrm{m}^{3}\right)$ on Day 65, Point $3\left(325.00 \mu \mathrm{g} / \mathrm{m}^{3}\right)$ on Day 68, Point $2(276.04$ $\left.\mu \mathrm{g} / \mathrm{m}^{3}\right)$ on Day 31 , and Point $1\left(183.56 \mu \mathrm{g} / \mathrm{m}^{3}\right)$ on Day 88 . Point 4 produces the highest $\mathrm{PM}_{10}$ concentration because the location is a hot blast plant area where air pollution is generated from coke oven or blast furnace activities. Blast furnaces have the most significant contribution in producing dust emissions because some dust is produced in a short time (Wang et al., 2016).

Furthermore, the point that identifies the second highest $\mathrm{PM}_{10}$ concentration is point 3, even though the

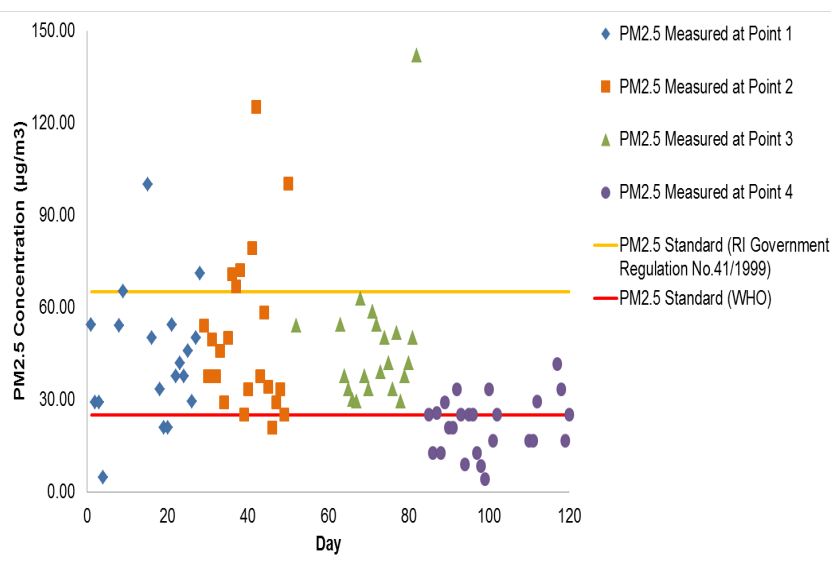

Figure 4. The $\mathrm{PM}_{2.5}$ concentration at each sampling point in the steel industry, Cilegon

lowest concentration of $\mathrm{PM}_{10}$ occurs on Day 11 at Point 3 $\left(16.67 \mu \mathrm{g} / \mathrm{m}^{3}\right)$, compare to other sampling location. This is caused by the location of Point 3 . Point 3 is a billet post area where the source of the pollution comes from transportation of factory supporting goods so that the main pollution produced is transportation dust. While this area is close to the Direct Reduction Plant and Slab Steel Plant, these plants are not produces the main product so the activities in the area is smaller.

Point 2 is a hot strip mill area where the concentration of $\mathrm{PM}_{10}$ produced is lower than Point 4 and Point 3 because the volume of production process activities in the area is smaller. And the smallest $\mathrm{PM}_{10}$ is produced at point 1 because the location is not included in the industrial process area or there is no production process activity.

The highest concentration of $\mathrm{PM}_{2.5}$ in the sequence were obtained from Point $3\left(141.96 \mu \mathrm{g} / \mathrm{m}^{3}\right)$ on Day 82, Point $2\left(125.21 \mu \mathrm{g} / \mathrm{m}^{3}\right)$ on Day 42, Point $1\left(99.88 \mu \mathrm{g} / \mathrm{m}^{3}\right)$ Day 15, and Point $4\left(41,67 \mu \mathrm{g} / \mathrm{m}^{3}\right)$ on Day 117 . However, the lowest concentration of $\mathrm{PM}_{2.5}$ is $4.19 \mu \mathrm{g} / \mathrm{m}^{3}$ obtained from Point 4 on Day 99. $\mathrm{PM}_{2.5}$ measurements are different from $\mathrm{PM}_{10}$, where $\mathrm{PM}_{2.5}$ measurements are carried out at different times for each location. Because of that, Point 4 produces $\mathrm{PM}_{2.5}$ at the lowest compared to other areas because of the rainfall at the time of sampling at Point 4 higher than others, where more particulate matters will be carried away by rainwater, so that it is not bound in filter paper, and the result of measured concentrations are smaller 


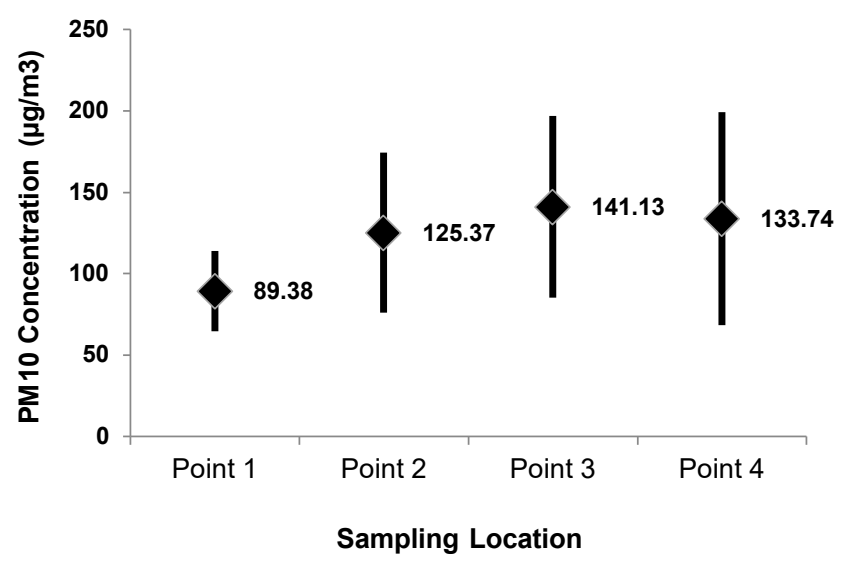

Figure 5. The average of $\mathrm{PM}_{10}$ concentrations at each sampling point in the steel industry area, Cilegon

(Alias et al., 2007). This study proves that particulate matters are affected by the weather (Yadav et al., 2017).

This is in accordance with the level and type of activities or processes at each point, in agreement with previous studies, due to the difference of raw materials, physical and chemical reactions, combustion environment, operating facilities, and the components (i.e., water-soluble ions, mineral elements and carbonaceous species) of particulate matters varied completely between processes in iron and steel industry. Average particle mass concentration (the size distributions of particle mass ranging between 0.43 and $10 \mu \mathrm{m})$ was found to be the highest at sintering sites $\left(40.8 \mathrm{mg} / \mathrm{m}^{3}\right)$, followed by Puddling, Steelmaking and then Rolling. The sintering process is regarded as the most important pollution source in iron and steel industry from where majority of gaseous pollutants were discharged, closely related to various manufacturing techniques and raw materials are involved in sintering process. Most of the gaseous pollutants, mainly $\mathrm{SO}_{2}$, were removed in desulfurizing tower through translating into the secondary water-soluble ions (e.g., $\mathrm{SO}^{2-}, \mathrm{NO}^{-}$), which are the important constituent parts of PM pollutants (Jia et al., 2018).

For the average, the concentration of $\mathrm{PM}_{10}$ and $\mathrm{PM}_{2.5}$ (Figure 5 and Figure 6) in the steel industry, Cilegon from September 2018 to January 2019 are as follows: 89.38 $\mu \mathrm{g} / \mathrm{m}^{3}$ and $43.64 \mu \mathrm{g} / \mathrm{m}^{3}$ at the Point $1 ; 125.37 \mu \mathrm{g} / \mathrm{m}^{3}$ and

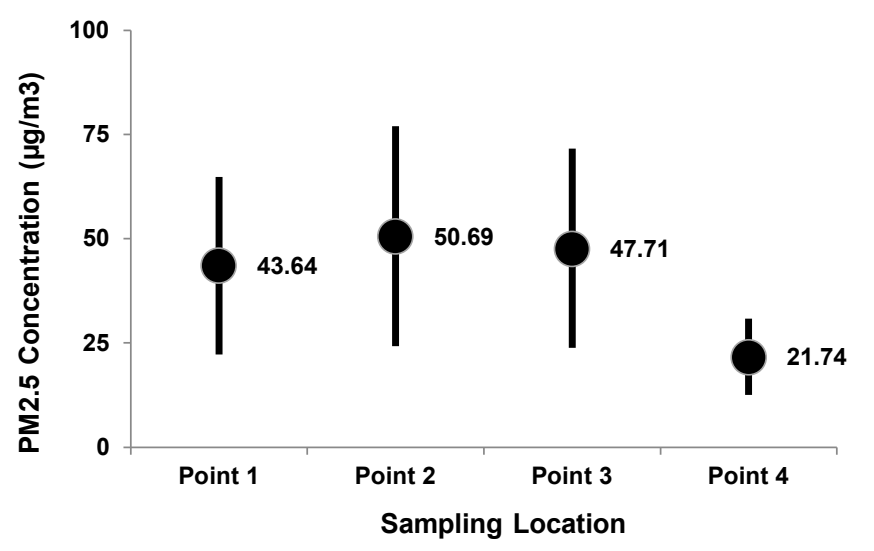

Figure 6. The average of $\mathrm{PM}_{2.5}$ concentrations at each sampling point in the steel industry area, Cilegon

$50.69 \mu \mathrm{g} / \mathrm{m}^{3}$ at Point $2 ; 141.13 \mu \mathrm{g} / \mathrm{m}^{3}$ and $47.71 \mu \mathrm{g} / \mathrm{m}^{3}$ in Point $3 ; 133.74 \mu \mathrm{g} / \mathrm{m}^{3}$ and $21.74 \mu \mathrm{g} / \mathrm{m}^{3}$ at Point 4 . Based on national ambient air quality standards, the average concentration at each sampling location point is still below the quality standard of $\mathrm{PM}_{10}\left(150 \mu \mathrm{g} / \mathrm{m}^{3}\right)$ and the quality standard of $\mathrm{PM}_{2.5}\left(65 \mu \mathrm{g} / \mathrm{m}^{3}\right)$ (RI Government Regulation Number 41 of 1999). However, the average concentration obtained does not meet the world air quality standards issued by World Health Organization (WHO), namely 50 $\mu \mathrm{g} / \mathrm{m}^{3}$ for $\mathrm{PM}_{10}$ and $25 \mu \mathrm{g} / \mathrm{m}^{3}$ for $\mathrm{PM}_{2.5}$ (WHO, 2018), only $\mathrm{PM}_{2.5}$ in Point 4 meets the required is $21,74 \mu \mathrm{g} / \mathrm{m}^{3}$.

\section{CONCLUSION}

The concentrations of $\mathrm{PM}_{10}$ in the steel industry area, Cilegon, Indonesia is around $20.83-183.56 \mu \mathrm{g} / \mathrm{m}^{3}$ in Point 1, $25.00-276.04 \mu \mathrm{g} / \mathrm{m}^{3}$ in Point 2, 16.67 - 325.00 $\mu \mathrm{g} / \mathrm{m}^{3}$ in Point 3, and $37.53-338.06 \mu \mathrm{g} / \mathrm{m}^{3}$ in Point 4 . While, the concentrations of $\mathrm{PM}_{2.5}$ is around $4.59-99.88$ $\mu \mathrm{g} / \mathrm{m}^{3}$ at Point 1, $20.83-125.21 \mu \mathrm{g} / \mathrm{m}^{3}$ at Point 2, 29.25 $141.96 \mu \mathrm{g} / \mathrm{m}^{3}$ in Point 3 and $4.19-41.67 \mu \mathrm{g} / \mathrm{m}^{3}$ in Point 4. Some values met the permissible daily limit (Republic of Indonesia Government Regulation Number 41 Year 1999) of $150 \mu \mathrm{g} / \mathrm{m}^{3}$ for $\mathrm{PM}_{10}$ and $65 \mu \mathrm{g} / \mathrm{m}^{3}$ for $\mathrm{PM}_{2.5}$ and some exceed it.

The maximum concentration of $\mathrm{PM}_{10}$ measured was $338.06 \mu \mathrm{g} / \mathrm{m}^{3}$ at Point 4 (the hot blast plant area) on 
Day 65 and the minimum concentration was $16.67 \mu \mathrm{g} / \mathrm{m}^{3}$ at Point 3 (the billet post area) on Day 11. While, the maximum concentration of $\mathrm{PM}_{2.5}$ was $141.96 \mu \mathrm{g} / \mathrm{m}^{3}$ at Point 3 on Day 82 and the minimum concentration was $4.19 \mu \mathrm{g} / \mathrm{m}^{3}$ at Point 4 on Day 99 .

\section{ACKNOWLEDGMENT}

The researcher thanked Aerosol Research and Technology (ART) Plus, Korea for supporting this research activity.

\section{REFERENCES}

Alias, M., Z. Hamzah, \& Kenn, L. S. (2007). $\mathrm{PM}_{10}$ and Total Suspended Particulates (TSP) Measurements in Various Power Stations. The Malaysian Journal of Analytical Sciences, 11(1): 255-261

Amaral, S. S., Jr., J. A. C., Costa, M. A. M., \& Pinheiro, C. (2015). An Overview of Particulate Matter Measurement Instruments. Atmosphere, 6: 13271345. doi: 10.3390/atmos6091327

Budde, M., Masri, R. E., Riedel, T., \& Beigl, M. (2013). Enabling Low-Cost Particulate Matter Measurement of Participatory Sensing Scenarios. Proceeding of the $12^{\text {th }}$ International Conference on Mobile and Ubiquitous Multimedia, Lulea, Sweden, Dec. 2-5, 2013. doi: $10.1145 / 2541831.2541859$

Jia, J., Cheng, S., Yao, S., Xu, T., Zhang, T., Ma, Y., Wang, H., \& Duan, W. (2018). Emission Characteristics and Chemical Components of Size-Segregated Particulate Matter in The Iron and Steel Industry. Atmospheric Environment, 182: 115-127. doi:10.1016/j.atmosenv.2018.03.051

Kumar, S. S., Muthuselvam, P., Pugalenthi, V., Subramanian, N., Ramkumar, K.M., Suresh, T., Suzuki, T., \& Rajaguru, P. (2018). Toxicoproteomic Analysis of Human Lung Epithelial Cells Exposed to Steel Industry Ambient Particulate Matter (PM) Reveals Possible
Mechanism of PM Related Carcinogenesis. Environmental Pollution, 239: 483-492. doi:10.1016/j.envpol.2018.04.049

Owoade, K. O., Hopke, P. K., Olise, F. S., Ogundele, L. T., Fawole, O. G., Olaniyi, B. H., Jegede, O. O., Ayoola, M. A., \& Bashiru, M. I. (2015). Compositions and Source Identification of Particulate Matter $\left(\mathrm{PM}_{2.5}\right.$ and $\left.\mathrm{PM}_{2.5-10}\right)$ from a Scarp Iron and Steel Smelting Industry Along the Ife-Ibadan Highway, Nigeria. Atmospheric Pollution Research, 6: 107-119. doi:10.5094/APR.2015.013

Republik Indonesia. (1999). RI Government Regulation No.41: Pengendalian Pencemaran Udara. Jakarta Ruhiat, Y., Syafrizal, Hidayat, S., Indrayono, Y., \& Akbar, H. (2017). Estimated Contaminated Area of Air Pollutant from Industrial in Cilegon. Research Journal of Environmental Sciences, 11(3): 108115. doi:10.3923/rjes.2017.108.115

Roychowdhury, A., Chattopadhyaya, V., \& Shukla, S. (2016). Reinventing Air Quality Monitoring: Potential of Low Cost Alternative Monitoring Methods. New Delhi: Centre for Science and Environment

Standar Nasional Indonesia (SNI) 7119.15:2016. (2016). Udara Ambien - Bagian 15: Cara Uji Partikel dengan Ukuran $\leq 10 \mu \mathrm{m}\left(\mathrm{PM}_{10}\right)$ Menggunakan Peralatan High Volume Air Sampler (HVAS) dengan Metode Gravimetri. Jakarta: Badan Standardisasi Nasional

U. S. EPA (United States Environmental Protection Agency). (2018). Particulate Matter (PM) Pollution. $\quad$ https://www.epa.gov/pm-pollution (accessed April 13 $3^{\text {th }}$ 2019)

Wahab, S. A., Fadlallah, S., \& Al-Rashdi, M. (2018). Evaluation of The Impact of Ground-Level Concentrations of $\mathrm{SO}_{2}, \mathrm{NO}_{\mathrm{x}}, \mathrm{CO}$, and $\mathrm{PM}_{10}$ Emitted from a Steel Melting Plant on Muscat, Oman. Sustainable Cities and Society, 38: 675683. doi:10.1016/j.scs.2018.01.048 
Wang, K., Tian, H., Hua, S., Zhu, C., Gao, J., Xue, Y., Hao, J., Wang, Y., \& Zhou, J. 2016. A Comprehensive Emission Inventory of Multiple Air Pollutant from Iron and Steel Industry in China: Temporal Trends and Spatial Variation Characteristics. Science of the Total Environment, 559: 7-14. doi:10.1016/j.scitotenv.2016.03.125

Air Quality Index Calculation. (2019). World-Wide Air Quality Monitoring Data Coverage. https://aqicn.org/sources/ (accessed April $15^{\text {th }}$ 2019)
World Health Organization. 2018. Ambient (outdoor) Air Quality and Health. https://www.who.int/newsroom/fact-sheets/detail/ambient-(outdoor)-airquality-and-health. (accessed January $28^{\text {th }} 2019$ )

Yadav, R., Sahu, L. K., Beig, G., Tripathi, N., \& Jaaffrey, S. N. A. (2017). Ambient Particulate Matter and Carbon Monoxide at An Urban Site of India: Influence of Anthropogenic Emissions and Dust Storms. Environmental Pollution, 225: 291-303. doi:10.1016/j.envpol.2017.01.038 